Hydrol. Earth Syst. Sci. Discuss., 6, 6659-6690, 2009 www.hydrol-earth-syst-sci-discuss.net/6/6659/2009/ (c) Author(s) 2009. This work is distributed under the Creative Commons Attribution 3.0 License.

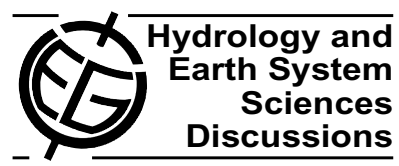

This discussion paper is/has been under review for the journal Hydrology and Earth System Sciences (HESS). Please refer to the corresponding final paper in HESS if available.

\title{
Hydroclimate variability and its statistical links to the large-scale climate indices for the Upper Chao Phraya River Basin, Thailand
}

\author{
N. Singhrattna ${ }^{1}$, M. S. Babel ${ }^{1}$, and S. R. Perret ${ }^{1,2}$ \\ ${ }^{1}$ Water Engineering and Management, Asian Institute of Technology, Pathumthani, Thailand \\ ${ }^{2}$ Centre de Coopération Internationale en Recherche Agronomique pour le Développement, \\ UMR G-Eau, Montpellier, France \\ Received: 19 October 2009 - Accepted: 20 October 2009 - Published: 30 October 2009 \\ Correspondence to: N. Singhrattna (nkrintra.singhrattna@ait.ac.th) \\ Published by Copernicus Publications on behalf of the European Geosciences Union.
}

6659

\begin{abstract}
The local hydroclimates get impacts from the large-scale atmospheric variables via atmospheric circulation. The developing of their relationships could enhance the understanding of hydroclimate variability. This study focuses on the Upper Chao Phraya

5 River Basin in Thailand in which rainfall is influenced by the Indian Ocean and tropical Pacific Ocean atmospheric circulation. The Southwest monsoon from the Indian Ocean to Thailand is strengthened by the temperature gradient between land and ocean. Thus, the anomalous sea surface temperature (SST) is systematically correlated with the monthly rainfall and identified as the best predictor based on the significant relation-

10 ships revealed by cross-correlation analysis. It is found that rainfall, especially during the monsoon season in the different zones of study basin, corresponds to the different SST indices. This suggests that the region over the ocean which develops the temperature gradient plays a role in strengthening the monsoon. The enhanced gradient with the SST over the South China Sea is related to rainfall in High Rainfall Zone (HRZ);

5 however, the anomalous SST over the Indian Ocean and the equatorial Pacific Ocean are associated with rainfall in Normal and Low Rainfall Zone (NRZ and LRZ) in the study area. Moreover, the identified predictors are related to the rainfall with lead periods of 1-4 months for the pre-monsoon rainfall and 6-12 months for the monsoon and dry season rainfall. The study results are very useful in developing rainfall forecasting models and consequently in the management of water resources and extreme events.
\end{abstract}

\section{Introduction}

The impacts of climate change are widely studied and reported in terms of spatial and temporal downscaling to diagnose the variability of regional hydroclimate (Smith and O'Brien, 2001). The anomalies of the climate variables known as atmospheric indices, e.g. the El Niño-Southern Oscillation (ENSO) can strengthen or weaken a monsoon. Thus, they are responsible for the variability of local hydroclimates such 
as temperature (Gershunov, 1998; Pavia et al., 2006), precipitation (Masiokas et al., 2006) and streamflow (Gutiérrez and Dracup, 2001; Meko and Woodhouse, 2005). Due to an anomalous phase, the responses of hydroclimates may not be experienced with the same level of variability. In some regions, the storms develop stronger and

5 more frequently (Cañón et al., 2007; Kim et al., 2006) whereas in other regions dry conditions are experienced with droughts (Mendoza et al., 2005) during longer periods (Schöngart and Junk, 2007). The impacts of anomalous phase have changed climate patterns not only along the coast, but also in regions distanced from it (Saravanan and Chang, 2000; Tereshchenko et al., 2002; Harshburger et al., 2002). Moreover, their 10 impacts are difficult to identify because they may be influenced by nearby oceans, e.g. the Indian Ocean and the Atlantic Ocean coupled by the atmospheric-oceanic circulation (Wu and Kirtman, 2004; Nagura and Konda, 2007). The teleconnection influence could be determined by the lag time of anomalous events up to several months after a phenomenon happens (Sourza Filho and Lall, 2003; Grantz et al., 2005) which makes 5 it difficult to understand.

The annual cycle of the Southeast Asian climate is dominated by the interactions between the complex terrain and a simple annual reversal of the surface monsoonal wind from the Indian Ocean to the equatorial Western Pacific Ocean including the South China Sea. During the seasonal development of surface winds, the Asian summer monsoon which develops due to the land-ocean temperature gradient is influenced by the sea surface temperature (SST) anomalies over the equatorial Eastern Indian Ocean (Goswami et al., 2006) and the tropical Pacific Ocean (Fasullo and Webster, 2002). The non-convective anomalies over the equatorial Indian Ocean tend to weaken the convection over the Bay of Bengal, the Eastern Indian Ocean, Southeast Asia and the equatorial Western Pacific Ocean (Krishnan et al., 2000). Thus, it is evident that ENSO affects the Asian summer monsoon and subsequently, monsoon rainfall. Generally, strong El Niño is associated with a weak monsoon and decreased rainfall, whereas it is the opposite for La Niña (Shrestha, 2000; Shrestha and Kostaschuk, 2005). However, the influences over a particular region have to be carefully investigated due to the

6661

different responses which make it hard to define a certain pattern of the regional climate and climate change. The lead-lag relationships between the anomalous atmospheric occurrences and the local climate responses are also of interest.

The objectives of this research are to study the climate characteristics of a basin 5 in the Upper Chao Phraya River Basin located in Thailand (Southeast Asia) and to investigate their relationships with the large-scale atmospheric variables, such as the anomalous SST over the Pacific Ocean and Indian Ocean.

\section{The study basin}

Thailand, located between the Indian Ocean and Gulf of Thailand which is connected 10 to the Pacific Ocean (Fig. 1), covers an area of $513115 \mathrm{~km}^{2}$ with a population of 62.4 million in 2005. Its climate is influenced by both the Indian Ocean and Pacific Ocean due to the land-ocean interrelated temperature gradients. Summer season from mid-February to mid-May is responsible for developing the land-ocean gradient that strengthens the Southwest monsoon from the Indian Ocean in the following rainy 15 season. The rainy season is caused by the Inter Tropical Convergence Zone (ITCZ) and by the Southwest monsoon, and pasts from mid-May to mid-October. Due to the low intensity and uncertainty of rainfall occurrence, the period from May to July is called pre-monsoon or transition period from summer to monsoon season. On the other hand, heavy rainfall occurs from August to October. The average annual rainfall in the country ranges between $1200-1600 \mathrm{~mm}$. Winter season is characterized by dry and cool winds brought by the Northeast monsoon from the mid-latitude starting from mid-October to mid-February. In terms of streamflow, Thailand generates about 289000 million $\mathrm{m}^{3} /$ year of total average runoff in 25 major river basins. However, only 38000 million $\mathrm{m}^{3} /$ year or $13.1 \%$ of the annual runoff can be stored in reservoirs and 25 supplied to various use sectors within the country (RID, 2007).

Chao Phraya River Basin (Fig. 1) is the largest basin among the 25 major basins covering an area of $178000 \mathrm{~km}^{2}$ or $35 \%$ of the country land area. Four major tributaries, 
namely Ping, Wang, Yom and Nan rivers, merge at Nakhon Sawan and form the Chao Phraya River. The portion above the confluence at Nakhon Sawan is called the upper Chao Phraya River Basin, whereas the portion below the confluence is called the lower Chao Phraya River Basin. The upper basin covers an area of $102635 \mathrm{~km}^{2}$ or $58 \%$ of 5 the Chao Phraya River Basin.

The Ping River Basin is located between $15^{\circ}-19^{\circ} \mathrm{N}$ latitude and $98^{\circ}-100^{\circ} \mathrm{E}$ longitude in the Northern Thailand and covers an area of $33899 \mathrm{~km}^{2}$ (Fig. 1). The river is $740 \mathrm{~km}$ long. There are many storage dams located along the Ping River and its tributaries. The Bhumipol Dam is the most important one; it was constructed for the purposes of

10 hydropower, agriculture, flood mitigation, fishery and transportation. It is $154 \mathrm{~m}$ high and $486 \mathrm{~m}$ long with the maximum storage capacity of 13462 million $\mathrm{m}^{3}$ and the installed capacity of $779.2 \mathrm{MW}$ of hydropower. In terms of land use, $71.46 \%$ of basin area is covered with forests, which are mostly located in the upstream or the origin of the Ping River. The remaining area which is along both sides of the river and the flat 15 plain downstream is covered by agricultural and residential use and water sources.

\section{Data}

\subsection{Hydroclimate data}

Two hydroclimate data sets, rainfall and temperature from the climatic stations located in and around the Ping River Basin, are used in this study. Both data are recorded 20 on daily basis. Out of 208 rainfall stations operated by the Royal Irrigation Department (RID), Thailand Meteorological Department (TMD) and Department of Water Resources (DWR) of Royal Thai Government, 50 stations are selected based on the length of time series and the occurrence of incomplete data. Daily rainfall data observed at the selected stations are obtained from 1951 to 2006 with incomplete data less than $5 \%$ during the 30 recent year data. For daily air temperature, 11 stations of

6663

TMD are selected with the length of data varying from 16 to 56 years. The locations of selected rainfall and temperature stations are shown in Fig. 1.

\subsection{Large-scale atmospheric data}

The anomalous SST indices over the four different regions of the tropical Pacific Ocean

5 (Fig. 2) used in this study are provided by the Climate Prediction Center (CPC, 2007) of the US National Oceanic and Atmospheric Administration (NOAA). These are NINO $1+2$ (average SST over the area of $0^{\circ}-10^{\circ} \mathrm{S}$ latitude and $80^{\circ}-90^{\circ} \mathrm{W}$ longitude), NINO 3 (average SST over the area of $5^{\circ} \mathrm{N}-5^{\circ} \mathrm{S}$ latitude and $90^{\circ}-150^{\circ} \mathrm{W}$ longitude), NINO 3.4 (average SST over the area of $5^{\circ} \mathrm{N}-5^{\circ} \mathrm{S}$ latitude and $120^{\circ}-170^{\circ} \mathrm{W}$ longitude) and

$10 \mathrm{NINO} 4$ (average SST over the area of $5^{\circ} \mathrm{N}-5^{\circ} \mathrm{S}$ latitude and $150^{\circ} \mathrm{W}-160^{\circ} \mathrm{E}$ longitude). The Indian Ocean Index (ION) is the anomalous SST averaged over the region of $2^{\circ} \mathrm{N}-2^{\circ} \mathrm{S}$ latitude and $70^{\circ}-90^{\circ} \mathrm{E}$ longitude (Fig. 2). The ION is provided by the Physical Sciences Division of NOAA (PSD, 2007). The indices are calculated from two data sets, which are the Comprehensive Ocean-Atmosphere Data Set (COADS) (Woodruff

15 et al., 1993) and real-time surface marine data from the National Centers for Environmental Prediction (NCEP). In this study, the monthly data of all five indices (NINO 1+2, NINO 3, NINO 3.4, NINO 4 and ION) from 1950 to 2007 are used which all indices are estimated from the SST; however, the pressure at different levels can be also used to develop the statistical relationships as shown in Zehe et al. (2006a).

\section{$20 \quad 4$ Methodology}

To understand the different influences of large-scale atmospheric variables on local hydroclimate such as rainfall, the 50 selected rainfall stations are divided into three groups by using the median of annual rainfall. A station is defined as high rainfall station if its annual rainfall median (1951-2006) is greater than the 90th percentile of 2550 stations. The low rainfall station is defined by its annual rainfall median being below 
the 10th percentile of 50 stations. Stations not falling under the above categories are defined as normal rainfall stations. There are five stations identified under each high rainfall and low rainfall groups. The remaining 40 stations are normal rainfall stations (Fig. 3). The classification of rainfall stations also shows that all five high rainfall stations 5 are located in the upper region of the Ping River Basin or between $19^{\circ}$ and $20^{\circ} \mathrm{N}$ latitude which area is mostly covered by forests as mentioned above. In this paper, this area is called the High Rainfall Zone (HRZ). The normal and low rainfall stations are located in the middle and lower regions or between $15^{\circ}$ and $19^{\circ} \mathrm{N}$ latitude which areas are called the Normal Rainfall Zone (NRZ) and Low Rainfall Zone (LRZ), respectively.

10 The further analyses and comparison of results are done among these three groups of rainfall stations or zones of rainfall amount.

For climate diagnostics, since monthly rainfall of all selected stations are well correlated with significance at $95 \%$ confidence level by the Fisher's Transformation (Haan, 2002), the average values are calculated over five stations in both $H R Z$ and LRZ and

1540 stations in NRZ. For temperature, the average is estimated over 11 selected stations which are statistically correlated at $95 \%$ confidence level. The analyses cover monthly and seasonal variability of both rainfall and temperature. Moreover, the long-term links between seasonal temperature and rainfall are investigated to reveal the important factors of a monsoon. The correlation maps are used to corroborate the different physical 20 mechanisms among the designated groups.

To statistically investigate the linear relationships between monthly rainfall at the 50 selected stations and the SST indices, cross-correlation analysis is applied. The correlation coefficient $(r)$ is used to evaluate whether there exists a significant relationship or not. The objectives of correlation analysis are to: (i) determine the influences on rainfall related to the SST anomalous indices; (ii) identify the best SST index for each month of rainfall; and (iii) determine what is the predictable lead-time corresponding to the best index obtained from objective (ii) as mentioned above. The correlations obtained from three groups of rainfall stations may help in differentiating the influences of large-scale climate variables on monthly rainfall. Moreover, the cross-

6665

correlation analysis is done with combination cases of five SST indices, i.e. NINO 1+2, NINO 3, NINO 3.4, NINO 4, ION and 12 months of rainfall with lead-time varying from 1 to 12 months for each index. Hence, a total of 36,000 correlation coefficients (50 stations $\times 5$ indices $\times 12$ months $\times 12$ lead periods) are obtained from the analysis.

5 The best predictor for each month of rainfall and of an individual group is then identified from the total number of the significant correlations over all the stations under the group and 12 lead periods. For example, under HRZ stations, 60 correlations (5 stations $\times 12$ lead periods) are obtained for each month of rainfall and each SST index. Then, the total significant correlations from these 60 values are compared among

10 five indices to identify the best predictor. The predictable lead-time corresponding to the best predictor is also selected on the persistence of the significant correlations over the rainfall stations within a group.

\section{Result and discussion}

\subsection{Interannual climate diagnostic}

15 The annual cycles of air temperature and rainfall in the Ping River Basin are shown in Fig. 4a and b, respectively. The summer season (Fig. 4a) is observed during MarchApril-May (MAM). The maximum temperature of $30.2^{\circ} \mathrm{C}$ is observed in April, whereas the minimum temperature of $22.9^{\circ} \mathrm{C}$ occurs in December. Figure $4 \mathrm{~b}$ shows that rainfall is bi-modal with two peaks; one in May and another in August. Considering the primary

20 peak, the rainy or monsoon season in the basin occurs during August-SeptemberOctober (ASO) which is consistent over all three groups of rainfall stations. Moreover, the secondary peak, which is also experienced in all zones, is observed during MayJune-July (MJJ) which is the pre-monsoon season. This annual cycle corroborates with those observed by Singhrattna et al. (2005a). They explained that the secondary peak

25 of the pre-monsoon is related to the Southwest monsoon and the ITCZ passing from the Indian Ocean to Thailand in May and to the South China Sea and central China in 
mid-June. On the other hand, the primary peak is associated with ITCZ as it moves back to cover Thailand during ASO. This can also explain the maximum rainfall of $316.4 \mathrm{~mm}$ observed in August in the HRZ, and maximum rainfall of 236.6 and $208.6 \mathrm{~mm}$ in September in the NRZ and LRZ, respectively. The shift of the peaks is not only

5 because of the movement of ITCZ, but also due to the location of rainfall stations. HRZ stations are located in the upper region of the Ping River Basin; therefore, the ITCZ passes this area as it moves down from central China before passing the lower regions or the NRZ and LRZ simultaneously. This clearly explains why the maximum rainfall in the HRZ is observed a month earlier than those in the NRZ and LRZ. The pre-monsoon

10 (MJJ) and monsoon season (ASO) rainfall is about $87-89 \%$ of the total annual rainfall. The remaining is the dry season rainfall. Based on the criterion of less than $50 \mathrm{~mm}$ a month, the dry season covers the months of November to April of the following year.

\subsection{Interseason climate diagnostic}

The air temperature is related with rainfall in terms of developing the gradient between

15 land and sea which subsequently strengthens the monsoon. In this study, the summer season temperature is averaged over MAM. Temperature and amount of rainfall are statistically correlated. Figure 5 shows a strong inverse relationship between the dry season rainfall and MAM temperature with significance at $95 \%$ confidence level $( \pm 0.26)$. As expected, if the more rainfall is received during November to April, it would

20 tend to cool the land and atmosphere, thus decreasing the air temperature during MAM and vice versa. This is observed consistently over all three zones of rainfall stations. The MAM temperature subsequently plays a role in driving pre-monsoon and monsoon season rainfall. Figure 6 shows the 20-year moving window correlations between the MAM air temperature and the MJJ and ASO rainfall. For the NRZ and LRZ, as the pos25 itive correlations indicate, the higher MAM air temperature increases the MJJ and ASO rainfall and vice versa. ASO rainfall has stronger relationship with MAM temperature ( $r=-0.227$ to 0.467$)$ than MJJ rainfall ( $r=-0.386$ to 0.443 ) because MJJ is the transition period from summer to monsoon season in which the land-ocean temperature 6667

gradient is not fully developed. Either MJJ or ASO rainfall is correlated consistently over both zones of rainfall. However, the MJJ and ASO rainfall in HRZ have weak and inverse correlations with MAM air temperature as presented in Fig. 6. To further enhance the understanding of land-sea temperature gradient that influences the sea5 sonal rainfall, the relationship between ASO rainfall in HRZ and NRZ and the MAM surface temperature of nearby oceans is investigated (Fig. 7a). For the HRZ, the negative correlations with $90 \%$ significant level $( \pm 0.22)$ are associated with the MAM land surface temperature especially over the study basin, but positive correlations are found over the South China Sea. The negative correlations are consistent with the 20-year 10 moving window correlations which verify the quality of data. Although inverse relationships were observed between ASO rainfall in NRZ and MAM surface temperature, a developing gradient of temperature (negative-positive correlations) between land and nearby oceans can be seen, i.e. the South China Sea for the HRZ and the tropical Pacific Ocean and Indian Ocean for the NRZ. These correlations are also found in 15 the MJJ rainfall of HRZ and NRZ (figures not shown). The low surface pressure over an ocean, a variable indicating enhanced monsoon, is also observed in the regions where monsoon developed. Figure $7 \mathrm{~b}$ shows the correlations between ASO rainfall and surface pressure which corroborate the sources of monsoon over the study basin. This supports the fact that the land-sea temperature gradient developed over the South

20 China Sea influences the seasonal rainfall in HRZ, whereas the gradient over the tropical Pacific Ocean and Indian Ocean affects the rainfall in NRZ. Thus, the temperature gradients developed from different sources bring the influences on rainfall in different regions within the basin. In addition, Zehe et al. (2006a) found that the circulation patterns for different levels of pressure bring the different scales of impacts on monsoon

25 rainfall. However, more investigation and detailed study are required to distinguish the influences on local hydroclimate due to the teleconnection.

The standardized anomaly time series of the dry season (November to April) rainfall is presented in Fig. 8. It shows slightly increasing trends over three rainfall groups. Over 54 years (1952 to 2005), based on linear trend, the increase is $53.6 \mathrm{~mm}$ for HRZ, 
$2.3 \mathrm{~mm}$ for $\mathrm{NRZ}$ and $3.9 \mathrm{~mm}$ for $\mathrm{LRZ}$. Based on the strong inverse correlations between the dry season rainfall and MAM temperature (Fig. 5), the increasing trends of the dry season rainfall tend to decrease the MAM temperature as shown in Fig. 9. There is a decrease of $0.6^{\circ} \mathrm{C}$ in the MAM temperature over 57 years of data. This trend is sta-

5 tistically significant at $95 \%$ confidence level by the standard $t$-test (Haan, 2002). This subsequently causes the decreasing trends in the MJJ and ASO rainfall as shown in Fig. 10 due to the weakening of development of land-sea temperature gradient. These trends are found for all three zones of rainfall stations, even in HRZ stations though its MJJ and ASO rainfall do not show strong response from the MAM temperature as

10 discussed in 20-year moving window correlations (see Fig. 6). From 1952 to 2005, the MJJ rainfall in LRZ shows maximum decreasing trend of $91.9 \mathrm{~mm}$ with $95 \%$ significant level, while rainfall in $\mathrm{HRZ}$ and $\mathrm{NRZ}$ show decreasing trends of 84.1 and $48.7 \mathrm{~mm}$, respectively. In addition, the ASO rainfall in NRZ exhibits the maximum decreasing trend of $133.0 \mathrm{~mm}$ (99\% significant level), whereas the decrease is 86.7 and $51.3 \mathrm{~mm}$ in HRZ

15 and LRZ, respectively. It is also important to note that the years reported as the warm phase of ENSO or EI Niño (Table 1) coincided with the below-normal MJJ and ASO rainfall, and vice versa during the La Niña years. This is corroborated by Singhrattna et al. (2005a) and Chen and Yoon (2000). Moreover, the decreasing trend of rainfall associates with the report of Intergovernmental Panel on Climate Change (Trenberth et al., 2007). They found based on the historical observations (1900-2005) that precipitation over the areas from $10^{\circ} \mathrm{N}$ to $30^{\circ} \mathrm{N}$ tended to decline since 1970 due to global warming and climate change. However, the precipitation fluctuated dependent upon region and season.

\subsection{Relationships to large-scale atmospheric indices}

\section{$25 \quad$ 5.3.1 Basin as a whole}

The links between rainfall in the study basin and ENSO have been found in the above diagnostic. Hence, cross-correlation analysis is systematically performed for the SST

$$
6669
$$

anomalous indices in order to further understand the relationships and identify the best predictors. From 36000 correlation coefficients obtained from the analysis, the significant correlations at $95 \%$ confidence levels are selected. The best predictors and corresponding lead periods to rainfall are summarized in Table 2. Considering all

550 selected stations and 12 monthly lead periods, the best index of individual month is identified based on the total number of significant correlations. For the MJJ (premonsoon season) rainfall, April NINO 3.4, February ION and June NINO 3 are the best predictors, respectively. For the ASO (monsoon season) rainfall, July NINO 3.4 (1-month lead) seems to be the best predictor for August rainfall, whereas February 10 NINO 4 (7-month lead) is the predictor for September rainfall. In addition, NINO 4 in November or December of the previous year (10- to 11-month lead) is the predictor for October rainfall. Furthermore, March NINO $1+2$ and April NINO 3 are identified for the dry season rainfall in November and December, respectively. For the JFM rainfall, ION in February of the previous year (11-month lead) found to be the best 15 predictor for January rainfall and July or August (December) ION for February (March) rainfall. The rainfall in the last month of the dry season, i.e. April is correlated with February NINO 3.4 which is 2-month lead. Therefore, it can be seen that the premonsoon season rainfall - i.e. MJJ has short-range lag relationships with SST indices up to 4 months. However, the monsoon (ASO) and the dry season (November to April)

20 rainfall have long-range lag relationships with SST indices except for August, March and April rainfall.

Based on the identified predictors, Fig. 11 shows the spatial coverage of the significant correlations over the study basin. The smallest coverage is found in September with only $11.7 \%$ of the study basin area. The spatial coverage in October, estimated 25 about $63.5 \%$ of the total land area, is the highest among 12 months. Interestingly, although rainfall during both months (September and October) is influenced by NINO 4, its impact is not experienced at the same spatial scale. The relationship between NINO 4 and rainfall initially develops in September, then becomes stronger and covers wider area during October and fades out in the following month. This confirms that a 
caution should be taken in studying and downscaling the impacts of climate change in term of the spatial and temporal scale because the local hydroclimate may not respond to the anomalous atmospheric variables with the same level (An et al., 2007; Mason and Goddard, 2001; Zehe et al., 2006a).

\section{5.3.2 Three zones of rainfall amount}

Looking at individual rainfall zones, the identified predictors for the pre-monsoon season (MJJ) are different among three zones of rainfall stations. As shown in Table 2, in May, the rainfall corresponds with April NINO 4 and NINO 3.4 for the HRZ stations, April NINO 3.4 for the NRZ stations and March or April NINO 1+2 for the LRZ stations.

10 For the June rainfall, the best predictor in the HRZ (NRZ) is NINO 1+2 (ION) during March to May (February). The LRZ stations have hardly any significant relationship with any of all five indices. In addition, the July rainfall relates with NINO 3 in May and June for the HRZ and June for the NRZ but with NINO 1+2 in March for the LRZ.

In the monsoon season (ASO), no significant correlation was found for the August

15 rainfall in the HRZ. This may be due to the fact that South China Sea is the dominant source of monsoon for the HRZ (Fig. 7). Links with the tropical Pacific Ocean and Indian Ocean are not found, either. However, September and October rainfall in the HRZ respond to the June NINO 3 (3-month lead) and April ION (6-month lead), respectively (Table 2). For NRZ and LRZ, monsoon season (ASO) rainfall has the same indices as the best predictors (see also Table 2). They refer to NINO 3.4 for the August rainfall and to NINO 4 for the September and October rainfall. However, the lead periods of indices are not consistent. The July NINO 3.4 or 1 -month lead is identified for the August rainfall in the NRZ, but it is NINO 3.4 in May to July for the LRZ. Moreover, the September rainfall in the NRZ corresponds with the February NINO 4 (7-month lead)

25 and with the same index in January, February and May for the LRZ. For October, the rainfall in the NRZ responds to NINO 4 in November or December and during November to January for the LRZ. Thus, it can be concluded that shorter lead period - i.e. 1-4 months of the identified predictors, was found for the pre-monsoon compared to 6671

the monsoon season, especially in September and October.

For the dry season (November to April) rainfall, the ION is basically related with rainfall during December to March especially in the HRZ and NRZ, whereas the anomalous SST over the tropical Pacific Ocean correlated with rainfall during the remaining months 5 (November and April) of the dry season. It is also shown that long-range relationships with selected SST indices vary from 5-12 months. However, short-lead periods of SST indices can be found in December rainfall in the HRZ, and March and April rainfall in the NRZ. The developed relationships between rainfall and indices or large-scale atmospheric variables would be useful in the development of rainfall forecasting models as presented in Singhrattna et al. (2005b) and Zehe et al. (2006b).

\section{Conclusions}

This study enhances the understanding of local hydroclimate variability and develops relationships between rainfall and SST anomalous indices. The land-sea temperature gradient plays a key role in strengthening or weakening monsoon over the Upper Chao

15 Phraya River Basin in Thailand. The amount of dry season (November to April) rainfall determines the MAM temperature which is responsible for setting up the temperature gradient in the study basin. Higher MAM temperature tends to increase pre-monsoon (i.e. MJJ) and monsoon (i.e. ASO) rainfall and vice versa. In terms of relationships with the anomalous atmospheric variables, the below- (above-) normal rainfall corresponds

20 to the El Niño (La Niña) phase of ENSO. As shown by the cross-correlation analysis, the best identified indices based on the significant relationships generally show 1-4 month lead predictability for the pre-monsoon season rainfall and 6-11 month lead predictability for the monsoon and dry season rainfall. For the monsoon rainfall, NINO 3.4 is the best predictor for the August rainfall and NINO 4 for the September 25 and October rainfall. The cross-relationship between October rainfall and five indices shows its significance covering a large area of the study basin. Rainfall during the remaining months (August and September), unlike the October rainfall, shows responses 
with different scales of spatial coverage. This suggests that caution must be taken in downscaling the impacts of teleconnections on the local hydroclimates. For different zones of rainfall, HRZ responds to different SST indices than those of NRZ and LRZ, especially during the monsoon months. This is due to the dominant regions of SST to 5 which the rainfall is related. The anomalous SST over the South China Sea influences the rainfall in the HRZ. However, the anomalous SST over the tropical Pacific Ocean and Indian Ocean has significantly influences the rainfall in the NRZ and LRZ. The lead-time relationships between the identified predictors and rainfall show that rainfall in the HRZ during January to April and October to November can be forecasted 6-12

10 months ahead. In the NRZ and LRZ, rainfall during September to February shows 5-12 month lead predictability. These lead-time relationships would be helpful in enhancing the performance of rainfall forecasting models, which development is an extension of the research presented here.

Acknowledgements. The authors would like to thank Sutat Weesakul and Kiyoshi Honda for the 15 invaluable comments. The authors also thank the Royal Irrigation Department (RID) of Thailand, the Thailand Meteorological Department (TMD) and the Department of Water Resources (DWR) for providing the data for the study. The first author is grateful to the Asian Institute of Technology, Thailand for the graduate fellowships, to the Department of Public Works and Town \& Country Planning for its kind support and to Piyawat Wuttichaikitcharoen for providing some

20 data used in this research. The research funding from CIRAD is gratefully acknowledged. Finally, the authors would like to thank editor, Erwin Zehe, and the anonymous reviewers whose comments improve the manuscript.

\section{References}

An, S. I., Kug, J. S., Timmermann, A., Kang, I. S., and Timm, O.: The influence of ENSO on the generation of decadal variability in the North Pacific, J. Climate, 20, 667-680, 2007.

Cañón, J., González, J., and Valdés, J.: Precipitation in the Colorado River basin and its low frequency associated with PDO and ENSO signal, J. Hydrol., 333, 252-264, 2007.

6673

Chen, T.-C. and Yoon, J.-H.: Interannual variation in Indochina summer monsoon rainfall: Possible mechanism, J. Climate, 13, 1979-1986, 2000.

CPC: The tropical Pacific Ocean SST indices, online available at: http://www.cpc.ncep.noaa. gov/data/indices, last access: December, 2007.

5 Fasullo, J. and Webster, P. J.: Hydrological signatures relating the Asian summer monsoon and ENSO, J. Climate, 15, 3082-3095, 2002.

Gershunov, A.: ENSO influence on intraseasonal extreme rainfall and temperature frequencies in the contiguous United States: Implications for long-range predictability, J. Climate, 11, 3192-3203, 1998.

10 Goswami, B. N., Wu, G., and Yasunari, T.: The annual cycle, intraseasonal oscillation, and roadblock to seasonal predictability of the Asian summer monsoon, J. Climate, 19, 50785099, 2006.

Grantz, K., Rajagopalan, B., Clark, M., and Zagona, E.: A technique for incorporating largescale climate information in basin-scale ensemble streamflow forecasts, Water Resour. Res., 41, W10410, doi:10.1029/2004WR003467, 2005.

Gutiérrez, F., and Dracup, J. A.: An analysis of the feasibility of long-range streamflow forecasting for Colombia using El Niño-Southern Oscillation indicators, J. Hydrol., 246, 181-196, 2001.

Haan, C. T.: Statistical method in hydrology, 2nd ed., lowa State Press, lowa, USA, 2002.

20 Harshburger, B., Ye, H., and Dzialoski, J.: Observation evidence of the influence of Pacific SSTs on winter precipitation and spring stream discharge in Idaho, J. Hydrol., 246, 157-169, 2002.

Kim, T. W., Valdés, J. B., Nijssen, B., and Roncayolo, D.: Quantification of linkages between large-scale climatic patterns and precipitation in the Colorado River basin, J. Hydrol., 321, 25 173-186, 2006.

Krishnan, R., Zhang, C., and Sugi, M.: Dynamics of breaks in the Indian summer monsoon, J. Atmos. Sci., 57, 1354-1372, 2000.

Masiokas, M. H., Villalba, R., Luckman, B. H., Quesne, C. L., and Aravene, J. C.: Snowpack variations in the central Andes of Argentina and Chile, 1951-2005: Large-scale atmospheric influences and implications for water resources in the region, J. Climate, 19, 6334-6352, 2006.

Mason, S. J. and Goddard, L.: Probabilistic precipitation anomalies associated with ENSO, B. Am. Meteorol. Soc., 82, 619-638, 2001. 
Meko, D. M. and Woodhouse, C. A.: Tree-ring footprint of joint hydrologic drought in Sacramento and upper Colorado river basins, western USA, J. Hydrol., 308, 196-213, 2005.

Mendoza, B., Jáuregui, E., Diaz-Sandoval, R., García-Acosta, V., Velasco, V., and Cordero, G.: Historical droughts in central Mexico and their relation with El Niño, J. Appl. Meteorol., 44, 709-716, 2005.

Nagura, M. and Konda, M.: The seasonal development of an SST anomaly in the Indian Ocean and its relationship to ENSO, J. Climate, 20, 38-52, 2007.

Pavia, E. G., Graef, F., and Reyes, J.: PDO-ENSO effects in the climate of Mexico, J. Climate, 19, 6433-6438, 2006.

10 PSD: The Indian Ocean SST index, online available at: http://www.cdc.noaa.gov/forecast1/ timeseries/index.html, last access: December, 2007.

RID: The 25 major river basins in Thailand (in Thai), online available at: http://www.rid.go.th, last access: August, 2007.

Saravanan, R. and Chang, P.: Interaction between tropical Atlantic variability and El NiñoSouthern Oscillation, J. Climate, 13, 2177-2194, 2000.

Schöngart, J. and Junk, W. J.: Forecasting the flood-pulse in Central Amazonia by ENSOindices, J. Hydrol., 335, 124-132, 2007.

Shrestha, A. and Kostaschuk, R.: El Niño/Southern Oscillation (ENSO)-related variability in mean-monthly streamflow in Nepal, J. Hydrol., 308, 33-49, 2005.

20 Shrestha, M. L.: Interannual variation of summer monsoon rainfall over Nepal and its relation to Southern Oscillation index, Meteorol. Atmos. Phys., 75, 21-28, 2000.

Singhrattna, N., Rajagopalan, B., Kumar, K. K., and Clark, M.: Interannual and interdecadal variability of Thailand summer monsoon season, J. Climate, 18, 1697-1708, 2005a.

Singhrattna, N., Rajagopalan, B., Clark, M., and Kumar, K. K.: Forecasting Thailand summer monsoon rainfall, Int. J. Climatol., 25, 649-664, 2005b.

Smith, S. R. and O'Brien, J. J.: Regional snowfall distributions associated with ENSO: Implications for seasonal forecasting, B. Am. Meteorol. Soc., 82, 1179-1191, 2001.

Sourza Filho, F. A. and Lall, U.: Seasonal to interannual ensemble streamflow forecasts for Cearra, Brazil: Applications of a multivariate semiparametric algorithm, Water Resour. Res., 39, 1307, doi:10.1029/2002WR001373, 2003.

Tereshchenko, I., Filonov, A., Gallesgos, A., Monzón, C., and Rodríguez, R.: El Niño 199798 and the hydrometeorological variability of Chapala, a shallow tropical lake in Mexico, J. Hydrol., 264, 133-146, 2002.

6675

Trenberth, K. E., Jones, P. D., Ambenje, P., Bojariu, R., Easterling, D., Tank, A. K., Parker, D., Rahimzadeh, F., Renwick, J. A., Rusticucci, M., Soden, B., and Zhai, P.: Observations: Surface and atmospheric climate change, IPCC, Cambridge University Press, Cambridge, United Kingdom and New York, NY, USA, 235-336, 2007.

5 Woodruff, S. D., Lubker, S. J., Wolter, K., Worley, S. J., and Elms, J. D.: Comprehensive OceanAtmosphere Data Set (COADS) Release 1a: 1980-92, Earth Syst. Monit., 4, 1-8, 1993.

Wu, R. and Kirtman, B. P.: Understanding the impacts of the Indian Ocean on ENSO variability in a coupled GCM, J. Climate, 17, 4019-4031, 2004.

Zehe, E., Singh, A. K., and Bárdossy, A.: Modelling of monsoon rainfall for a mesoscale catch-

10 ment in North-West India I: assessment of objective circulation patterns, Hydrol. Earth Syst. Sci., 10, 797-806, 2006a, http://www.hydrol-earth-syst-sci.net/10/797/2006/.

Zehe, E., Singh, A. K., and Bárdossy, A.: Modelling of monsoon rainfall for a mesoscale catchment in North-West India II: stochastic rainfall simulations, Hydrol. Earth Syst. Sci., 10, 807815, 2006b,

http://www.hydrol-earth-syst-sci.net/10/807/2006/. 
Table 1. Classification of Years according to El Niño and La Niña Phase of ENSO Defined by the Climate Prediction Center (CPC) and the Center for Ocean-Atmospheric Prediction Studies (COAPS).

\begin{tabular}{ll}
\hline Phase & Year \\
\hline El Niño & $\begin{array}{l}1951,1957,1963,1965,1968-69,1972,1976,1982-83,1986-87, \\
\\
1991-92,1994,1997-98,2002,2004,2006\end{array}$ \\
La Niña & $\begin{array}{l}1954-56,1964,1967,1970-71,1973-75,1988-89,1995,1999, \\
\\
2000\end{array}$ \\
\hline
\end{tabular}

6677

Table 2. Summary of the Best Predictors and Corresponding Lead Periods.

\begin{tabular}{|c|c|c|c|c|c|c|c|c|}
\hline \multirow{2}{*}{ Month } & \multicolumn{2}{|c|}{ Basin as a whole } & \multicolumn{2}{|c|}{ HRZ } & \multicolumn{2}{|r|}{ NRZ } & \multicolumn{2}{|c|}{ LRZ } \\
\hline & Index & Lead (months) & Index & Lead (months) & Index & Lead (months) & Index & Lead (months) \\
\hline Jan & ION & 11 & ION & $10-12$ & ION & 11 & ION & $8-11$ \\
\hline Feb & ION & $6-7$ & ION & $6-9$ & ION & $5-6$ & NINO 1+2 & $4-8,11-12$ \\
\hline Mar & ION & 3 & NINO 3 & 11 & ION & 3 & NINO 1+2 & $11-12$ \\
\hline Apr & NINO 3.4 & 2 & NINO 4 & 11 & NINO 3.4 & 2 & NINO 3 (3.4) & $2-4(2-4)$ \\
\hline May & NINO 3.4 & 1 & NINO 4 (3.4) & $1(1)$ & NINO 3.4 & 1 & NINO $1+2$ & $1-2$ \\
\hline Jun & ION & 4 & NINO 1+2 & $1-3$ & ION & 4 & - & - \\
\hline Jul & NINO 3 & 1 & NINO 3 & $1-2$ & NINO 3 & 1 & NINO 1+2 & 4 \\
\hline Aug & NINO 3.4 & 1 & - & - & NINO 3.4 & 1 & NINO 3.4 & $1-3$ \\
\hline Sep & NINO 4 & 7 & NINO 3 & 3 & NINO 4 & 7 & NINO 4 & $4,7-8$ \\
\hline Oct & NINO 4 & $10-11$ & ION & 6 & NINO 4 & $10-11$ & NINO 4 & $9-11$ \\
\hline Nov & NINO 1+2 & 8 & NINO 1+2 & 8 & NINO 1+2 & 8 & NINO 1+2 & 8 \\
\hline Dec & NINO 3 & 8 & ION & $1-2$ & NINO 3 & 8 & NINO 3 (3.4) & $7-10(7-10)$ \\
\hline
\end{tabular}




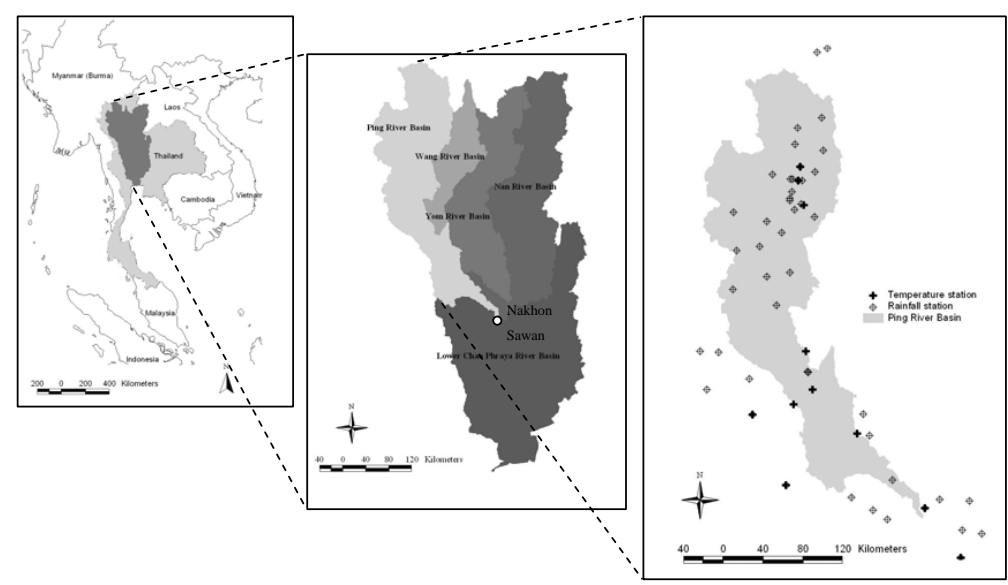

Fig. 1. Map of Thailand (left), Chao Phraya River Basin (middle) and Ping River Basin and locations of rainfall and temperature stations (right).

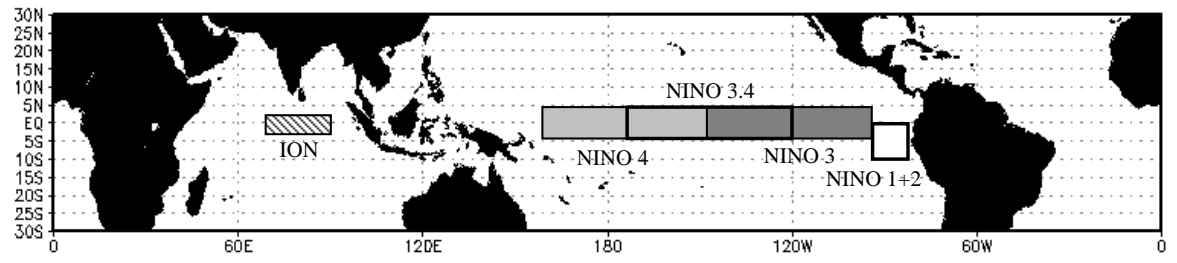

Fig. 2. SST index regions. 


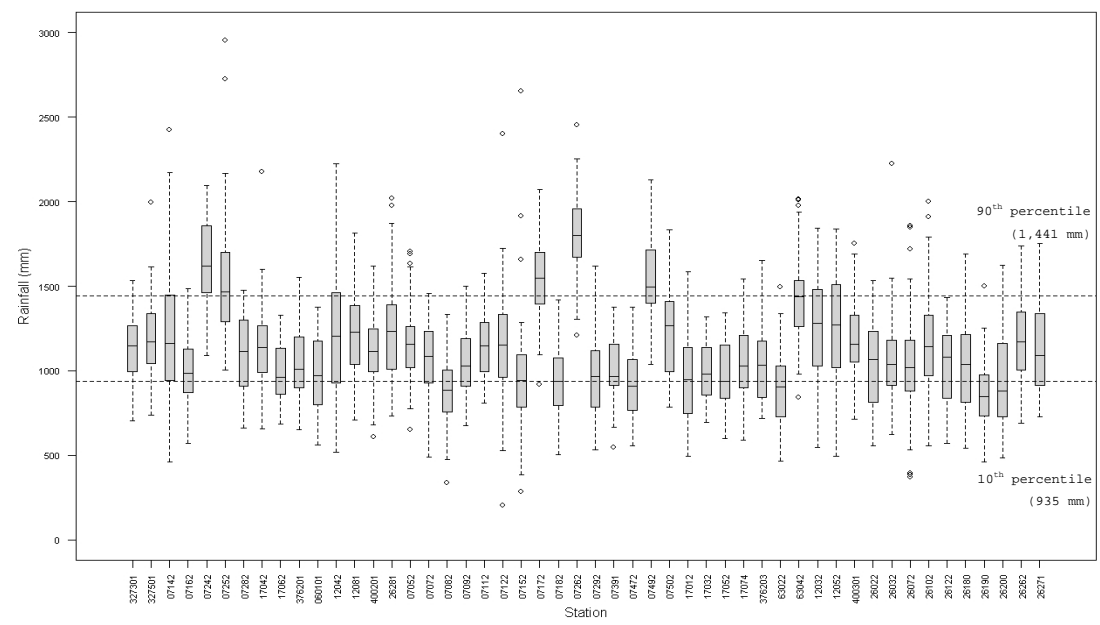

Fig. 3. Classification of rainfall stations based on the median of annual rainfall presented by a line inside a boxplot.
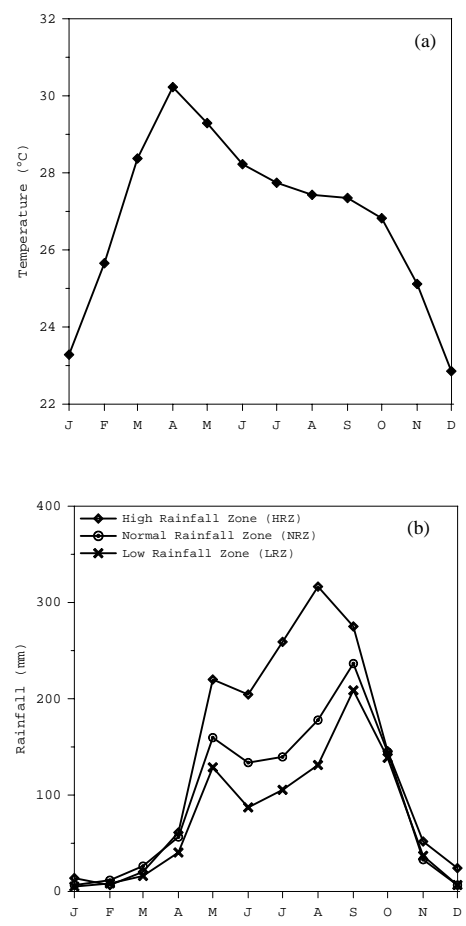

Fig. 4. Annual cycle of (a) temperature and (b) rainfall. 


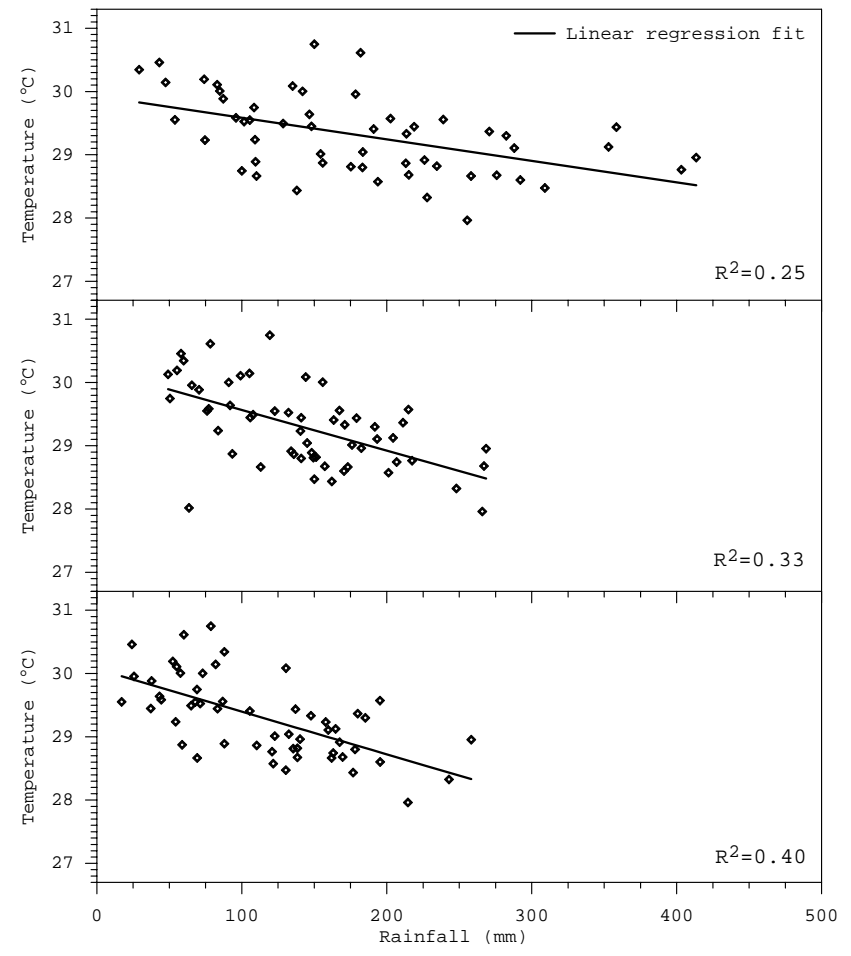

Fig. 5. Scatter plots between dry season (November to April) rainfall and MAM air temperature of HRZ (top), NRZ (middle), and LRZ (bottom).
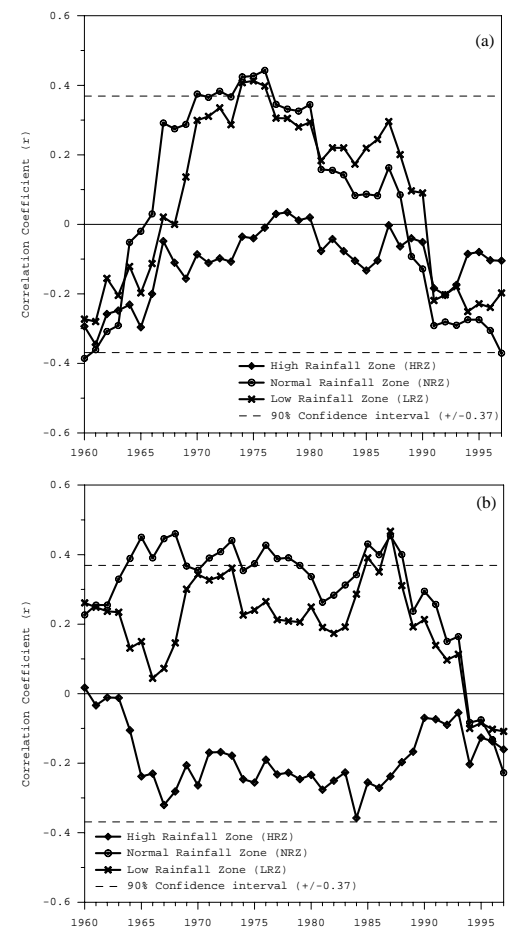

Fig. 6. Correlations of 20-year moving window between MAM temperature and (a) MJJ rainfall and (b) ASO rainfall. 

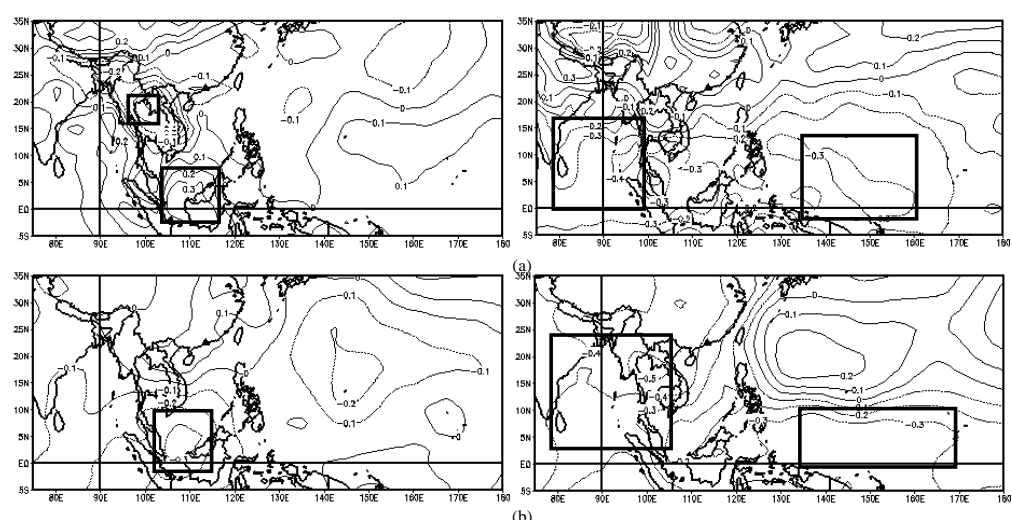

Fig. 7. Correlation maps between ASO rainfall and (a) MAM surface temperature and (b) ASO surface pressure for HRZ (left) and NRZ (right). The $90 \%$ significant levels are \pm 0.22 .

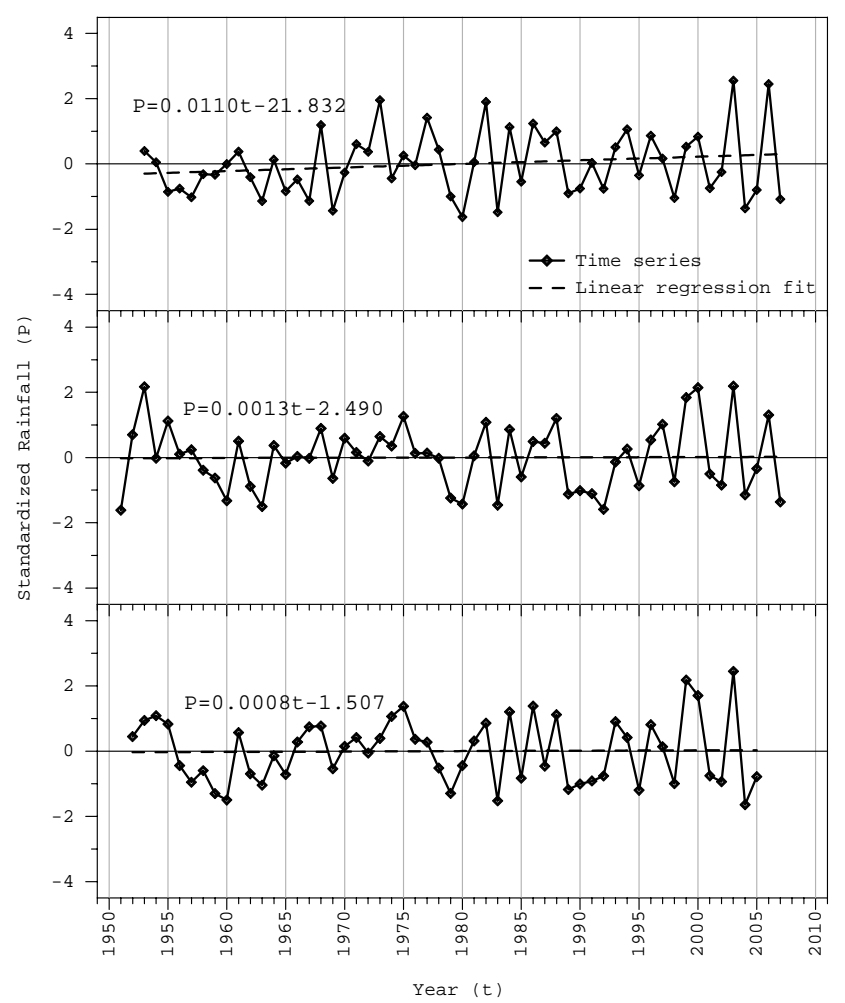

Fig. 8. Standardized anomaly time series of dry season rainfall $(P)$ for $\mathrm{HRZ}$ (top), NRZ (middle) and LRZ (bottom). 


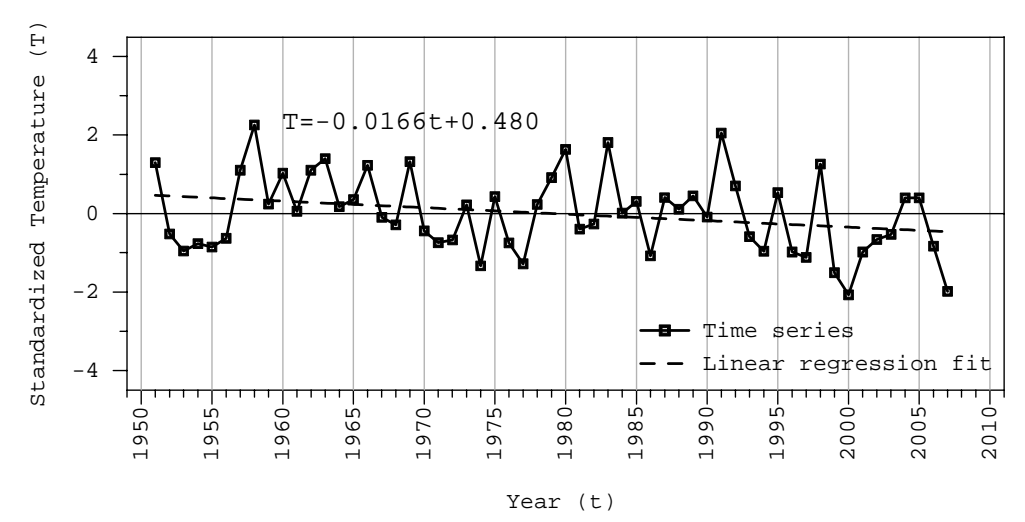

Fig. 9. Standardized anomaly time series of MAM temperature $(T)$.

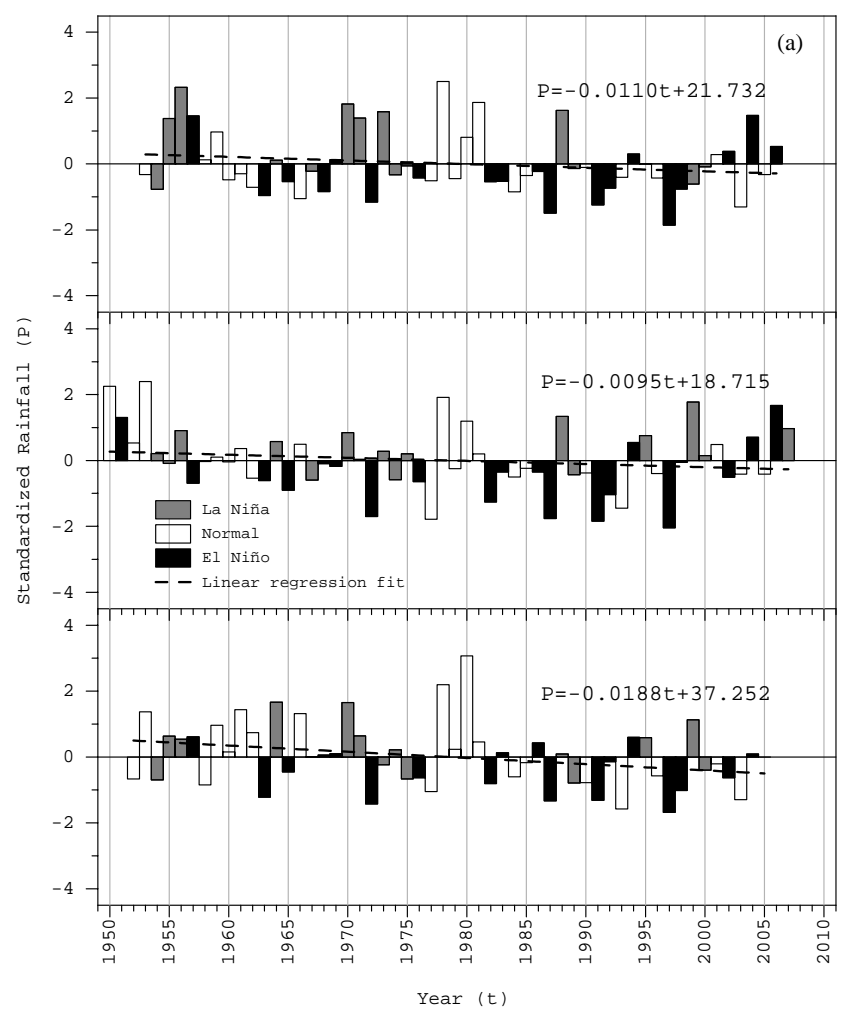

Fig. 10a. Standardized anomaly time series of rainfall $(P)$ for (a) MJJ and (b) ASO for HRZ (top), NRZ (middle) and LRZ (bottom). 


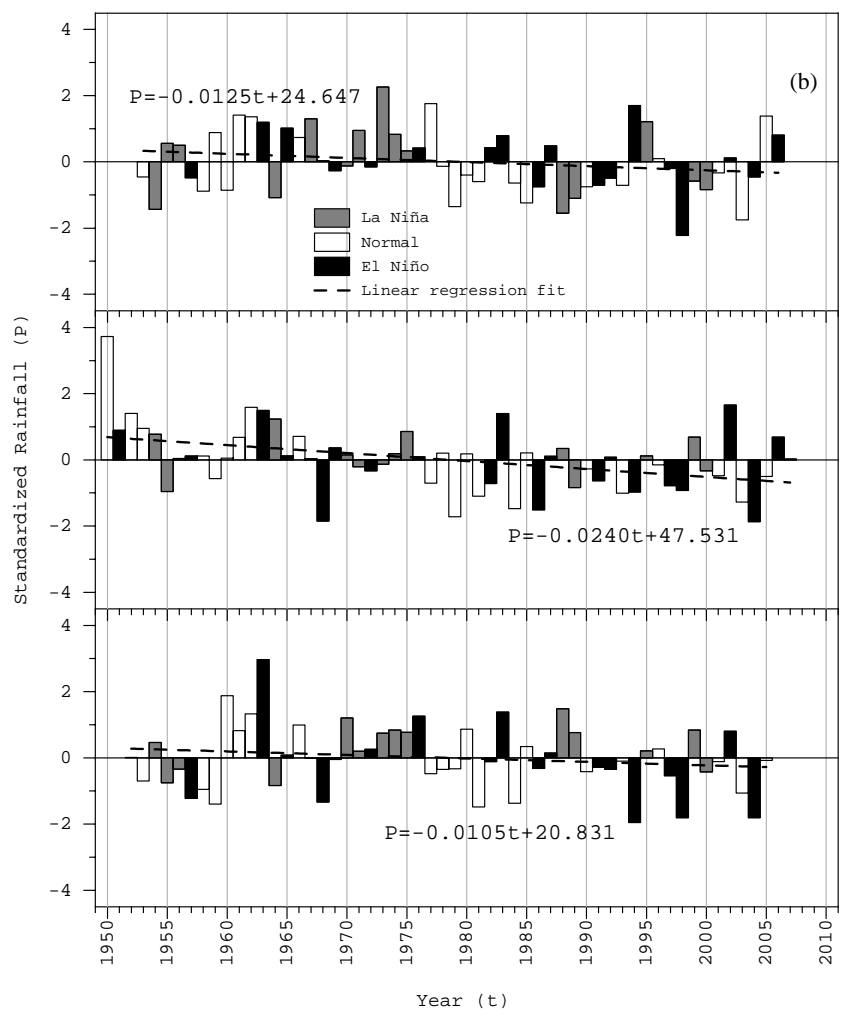

Fig. 10b. Continued.
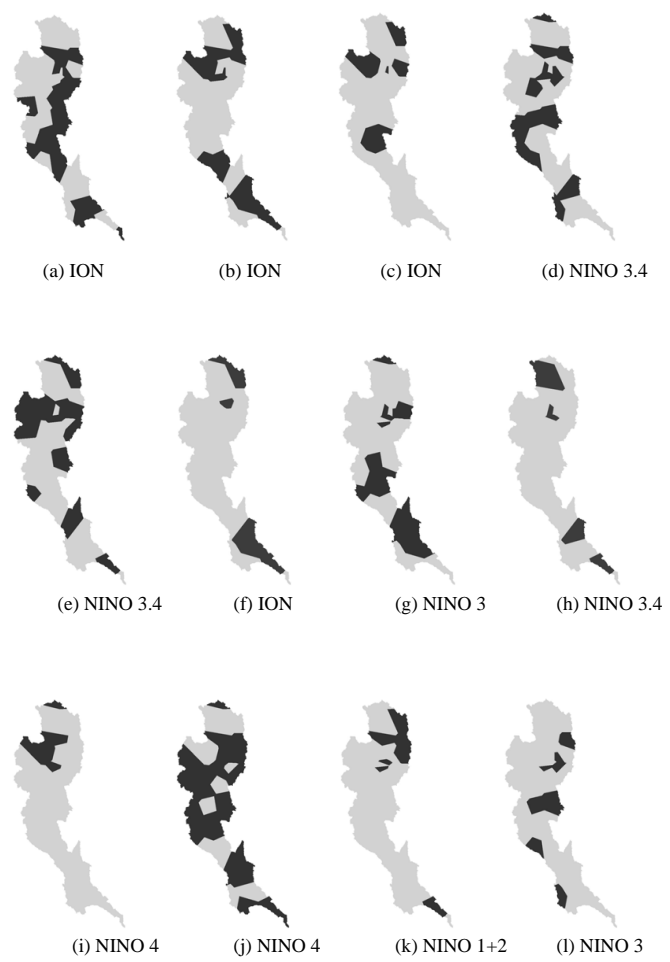

Fig. 11. Spatial coverage of significant correlations (in black) based on the identified best predictors from the cross-correlation analysis in January to December (a to I consecutively). 